\title{
100 万ボルト送電線の技術開発
}

\author{
上級会員 磯崎 正則* \\ Innovation on Energy Power Technology (12) \\ A Development of $1000 \mathrm{kV}$ Transmission Lines
}

Masanori Isozaki*, Senior Member

Since land of Japan is narrow, it is advantageous to enlarge the transmission capacity per one route in terms of environmental aspect and cost performance. Therefore, technological development, such as multiple transmission line, large size conductor, multiple conductors, high strength insulator and so on, has been promoted. Especially, the adoption of $1000 \mathrm{kV}$ transmission line is the final configuration of high voltage system, and it is the dream for overhead transmission line engineer. So, we intervened the engineer who engaged in the conceptual design of $1000 \mathrm{kV}$ transmission line in initial stage on the development situation at that time. It is considered that the method of solving the problems is useful for present engineer.

キーワード : 100 万ボルト, 送電線, 環境, 絶縁, 可聴音

Keywords: UHV, transmission line, environment, insulation, audible noise

\section{1. はじめに}

架空送電線の歴史は, 高電圧化と大容量化の歴史である。 絶縁を空気に頼っている架空送電線では, 高電圧化は回線 間や腕金間の距離の増大に伴う鉄塔の大型化を招く。一方, 国土の狭い日本では 1 ルートあたりの送電容量を大きくす ることが環境面・コスト面で有利であり，鉄塔の多回線化 や電線の太線化・多導体化, がいしの高強度化などの面で 技術開発が行われてきた。その中でも，100万ボルト送電 線 (以下 UHV 送電線) の導入は, 高電圧化の最終形態であ り，架空送電線技術者の夢であった。ここでは，検討の初 期段階に行われた概念設計に取り組んだ技術者に当時の検 討状況をうかがった。当時の課題の解決方法は現在の我々 の技術検討に当たっても参考になるものと思っている。

\section{100 万ボルト送電線の概要}

まず，日本における送電電圧の変遷を図 1 にまとめた。 昭和 30 年代初期までは 6.6 万ボルト送電線が主流であっ たが, その後, 送電電圧は, $15 \rightarrow 27 \rightarrow 50$ 万ボルトへと順次 高電圧化がはかられ, 現時点での最高電圧は 50 万ボルト である。

図 2 にUHV 送電線の経過地を, 表 1 に設備概要と特徴 をまとめた。柏崎刈羽原子力発電所から東山梨変電所に至

\footnotetext{
*東京電力 (株) 技術開発研究所

干 230-8510 横浜市鶴見区江ヶ崎町 4-1

R\&D Center, Tokyo Electric Power Company

4-1, Egasakicho, Tsurumi-ku, Yokohama 230-8510
}

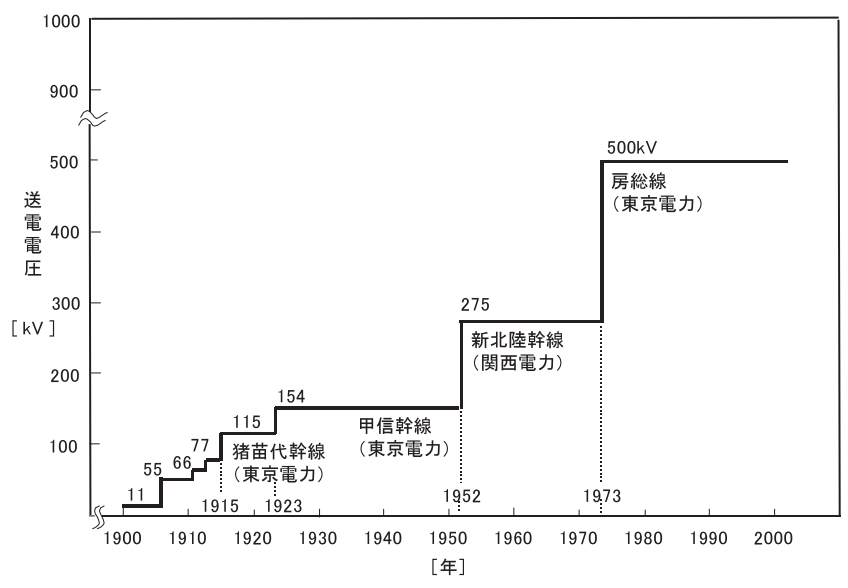

図 1 送電電圧の変遷

Fig. 1. Transition of transmission voltage.

る南北ルートは南新潟幹線と西群馬幹線から構成され, 山 岳地を通過することから, 重着水や強風などの過酷な気象 条件に基づく設計を一部行っているのが特徴である。

一方，南いわき開閉所から西群馬開閉所からに至る東西 ルートは南いわき幹線と東群馬幹線から構成され, 南北ルー トに比べ, 気象条件は緩やかであるものの, 丘陵地を通過 するため, 人家接近箇所も多く, 環境面での配慮から設計 を行っているのが特徵である。

図 3 には, 当時の検討結果から得られたUHV 送電線の 概念設計結果を示した。 50 万ボルト送電線技術を延長させ た結果, 鉄塔高は $143 \mathrm{~m}$ にも達しているが, 現在はさまざま 


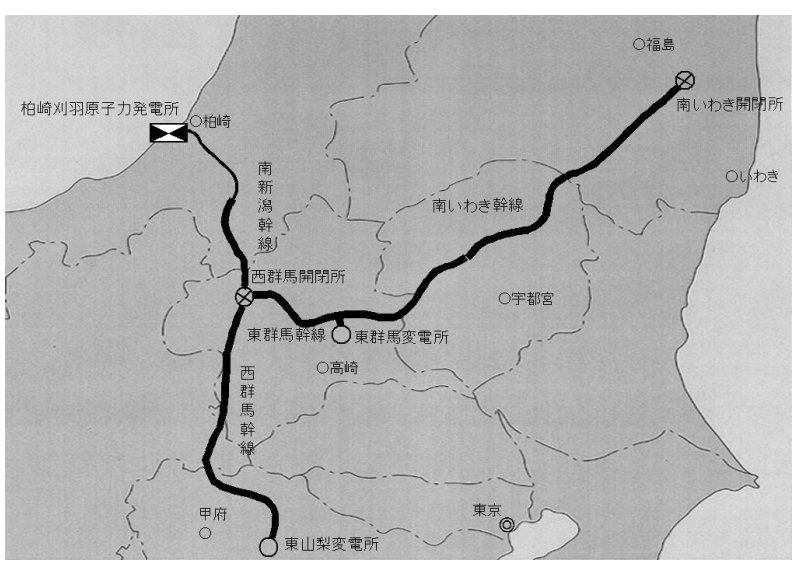

図 2 UHV 送電線の概要

Fig. 2. Outline of UHV transmission line.

表 1 UHV 送電線の概要と特徵

Table 1. Outline and feature of UHV transmission line.

\begin{tabular}{|c|c|c|}
\hline 線路名 & 線路概要 & 経過地と設備の特徵 \\
\hline 西群馬幹線 & 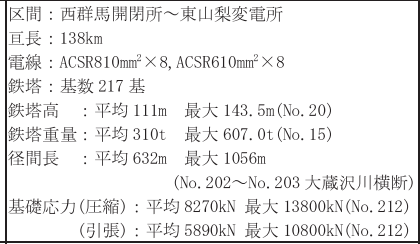 & 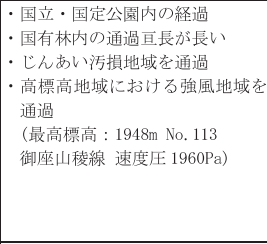 \\
\hline 南新潟幹線 & 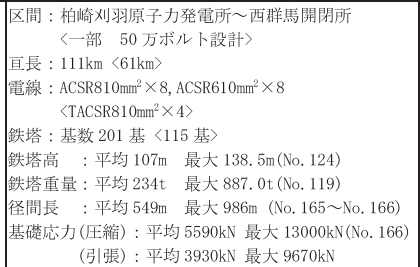 & 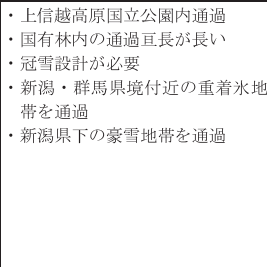 \\
\hline $\begin{array}{l}\text { 束群馬幹線 } \\
\text { (西群馬開閉所 } \\
\text { 東群馬変電所) } \\
\text { 南いわき幹線 } \\
\text { (№. 234〜 } \\
\text { 東群馬変電所) }\end{array}$ & 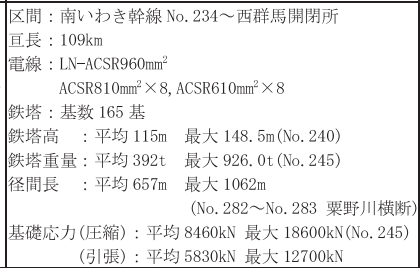 & 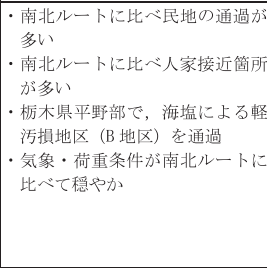 \\
\hline $\begin{array}{c}\text { (南いわき開閉 } \\
\text { ＮNo. 234) }\end{array}$ & 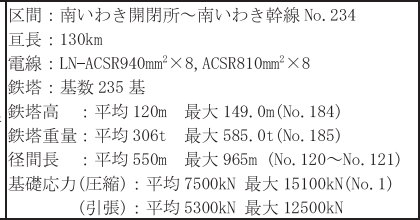 & 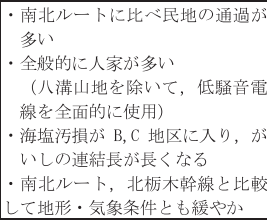 \\
\hline
\end{tabular}

なコンパクト化技術を開発し，120mにとどめている。鉄 塔をコンパクト化するために行った技術のうち，主なもの を表 2 に示した。

\section{3. 技術検討内容}

今回は東京電力（株）に在籍し, UHV 送電線の検討を 行っていた安井充氏に昭和 48 年当時を振り返っていただ いた。

〈3・1〉 検討開始にむけて 日本で初めての 50 万ボル 卜房総線が運転を開始した昭和 48 年，中央電力協議会の なかに, 関西電力, 中部電力, 電源開発, 東京電力の 4 社
$500 \mathrm{kV}$ 技術の延長

による UHV 鉄塔
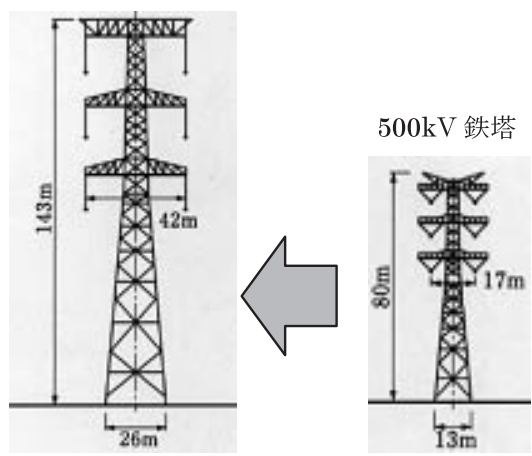

コンパクト化後 の UHV 鉄塔

図 3 UHV 鉄塔のコンパクト化

Fig. 3. Simplified UHV steel tower.

表 2 鉄塔合理化方策

Table 2. Measures of simplified steel tower.

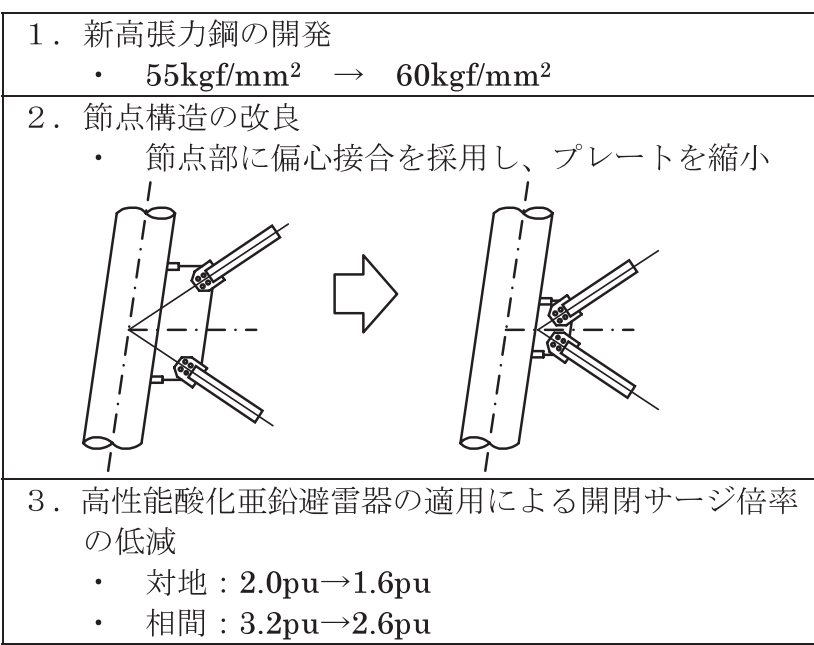

からなるUHV 開発推進委員会が設置され, UHV 送電線の 概念設計を実施することとなりました。まずは, UHV 送 電線の研究開発が日本よりも約 10 年も進んでいた海外に おける UHV 設備や実験成果の文献調査から検討を始めま した。質問状を作って相手に投げかけましたが，うれしい 事に，今までコンタクトのなかった北米，欧州の研究機関 が電中研，電力 4 社の訪問調査を受け入れてくれました。 UHV 送電線は電圧が倍になりますから, 絶縁と環境が問題 になることはわかっていましたので，特にその問題につい て，意見を交わしたいと思っていました。

〈3・2〉 絶縁技術ＩEEE に交流の污損がいしの非直線 性に関する論文が出され，大問題になりました。開閉サー ジの非直線性ならまだわかりますが，交流の污損がいしの 非直線性を設計に採用すると，がいし連がかなり長いもの になってしまいます。その原因を究明するため，米国政府 エネルギー省ボンネビル電力庁 (BPA) の霧室で行なわれた 同様の実験を見聞しましたが，半日やってもフラッシオー バしませんでした。その原因は，霧が薄いと特性がばらつ くということでした。結露しないとフラッシオーバは起こ 


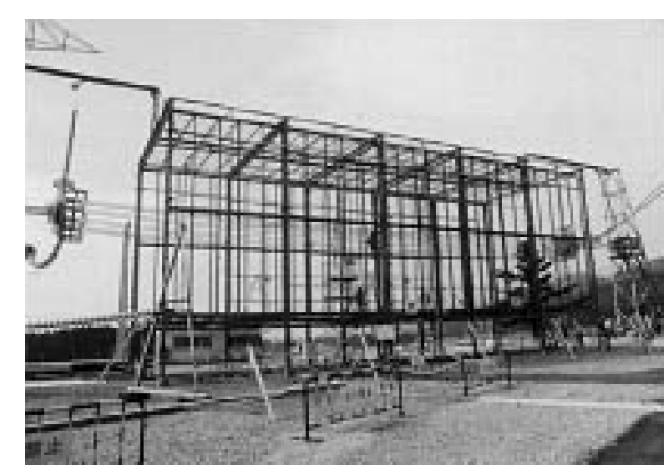

図 4 コロナケージ（塩原試験場）

Fig. 4. Corona cage (SHIOBARA test area).

らないということです。そこで，人工污損させたがいしを 冷蔵庫に入れて, それを常温に出して, 結露させてから試験 を行う方法を考え出しました。こうすることによって，交 流污損がいしの耐電圧には直線性があることがわかりまし た。現在では，均質な霧を作り出すことができるよう霧の 発生方法が格段に向上したので，このような方法はとって いないようですが，当時はそういう工夫を行ったというこ とです。行き詰った時には，人間は活路を見出すものだと 思います。

$\langle\mathbf{3} \cdot \mathbf{3}\rangle$ 可聴音対応送電電圧に比べ, 細すぎる電線 を採用すると，電線から可聴領域の騒音が発生します。こ れを総称してオーディブルノイズと言うのですが，当時こ れを熱心に研究していたのは GE の技術者でした。彼らは コロナケージという金網で囲まれたかご（ケージ，図 4)を 作って，その中に電線を架線し，騒音を計測していました。 もち万ん，実規模大の試験線も持っているのですが，多種 多様の電線状態の試験を試験線で行うには時間的にも研究 費的にも限界があって，コロナケージでの簡略的なデー夕 と試験線のデータとの関連から騒音の予測式を作っていま した。

しかし, 送電線の実際の運用状態では, 軽雨という状態 があります。これは霧や雨がしとしと降るような状態をさ していますが，このときは周囲の雑音，つまりべースノイ ズが低くなっているので，騒音は特に問題になります。こ の状態を模擬する上でコロナケージを用いて水量を減らし ていく方法では，うまく現象を表現できませんでした。と いうのも，風の状況によっては，雨滴は飛ばされてしまっ て電線にかからない可能性が高いからです。そこで，この 解決方法として彼らは，強雨状態で水をかけ，注水を止め た 1 分経過後に， 30 秒毎に 2 分間測定して，その平均值 を出して評価する方法を考え出していました。物理的な因 果関係は不明でしたが，コロナケージで測定した軽雨の值 が試験線における降雨時の50\%值にほぼ等しくなっていま した。だから，コロナケージを使ってパラメトリックスタ デイができました。これには非常に驚きました。後年に電 力中央研究所が群馬県赤城村に UHV 送電線の評価のため に試験線（図 5）を建設しますが，ここでの值もまさにそ

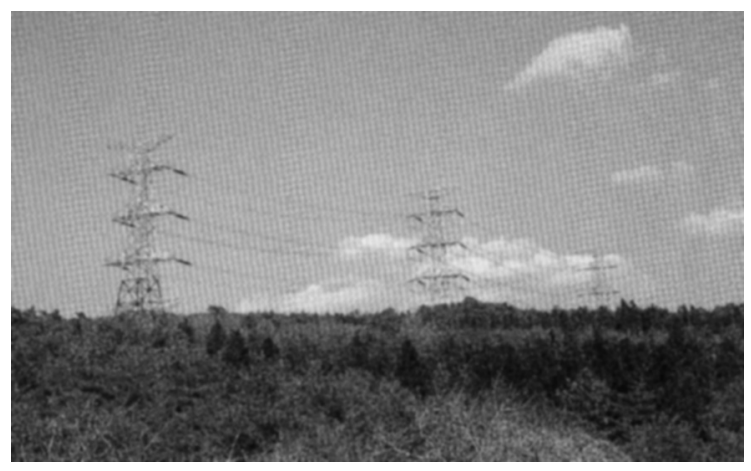

図 5 赤城試験線

Fig. 5. AKAGI test line.

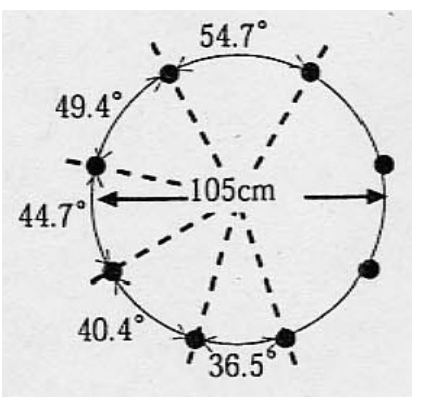

図 6 導体の非対称配列

Fig. 6. Arrangement of asymmetrical bundle.

の通りとなりました。

また，彼らはコロナ騒音の低減対策方法についても，検 討を行っていました。その方法は，上側の素導体間隔を広 げ，下側素導体の間隔を狭めるのです。こうすることによ り，下側の電位傾度を低くし，騒音を低減することができま す。この対策は，非対称化対策（図 6）と呼ばれています。 この技術についても，まずコロナケージでデータをとっ てから，赤城試験線のデータと照合しました。どのデータ も良く一致しました。このケージを使った軽雨という考え 方を含め, 海外のプロジェクトの勉強をしてきたことが非 常に短時間で UHV 送電線における検討の成果が出せたひ とつの要因だと思います。

騒音目標值の設定も大きな課題でした。各国における目 標值を参考にしましたが，もっとも厳しかった $40 \mathrm{~dB}$ とい う值を使うと電線構成が 10 導体になってしまったため, 日 本における 50 万ボルト送電線の実績を調査し, $50 \mathrm{~dB}$ を目 標值としました。これは，BPAでの目標值と同じでした。 これにより，導体構成は 8 導体となりました。

〈3・4〉若手の技術者のみなさんへ 最後に，若手の 電力技術者にメッセージを送りたいと思います。まず，自 分たちで開発・検討した技術が国内外で通用するか, でき れば論文としてまとめ, 学会に出してみることです。学会 論文がないと外国からは評価してもらえないからです。次 に，海外の状況をよく調査して，今後自分たちが進むべき 道を探してほしいということです。一例を挙げますと，日 


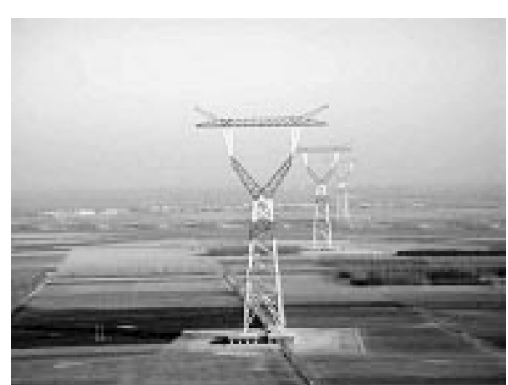

安徽送変電工程公司黄河大跨越項目部 HP より

図 7 中国 UHV 鉄塔

Fig. 7. UHV steel tower in China.

本より 10 年はやく超高圧送電線が運転開始した欧州の送 電線で起こっている不具合は，そのうち日本でも起こるは ずです。海外の研究開発者と連係をとりながら意見交換を していくことが重要と思います。今までに営々と築き上げ られた大電力系統を大過なく維持管理していくことが送電 技術者のやるべき重要な仕事になっていくと思います。ま た，これは技術継承にもなるはずです。

最後に，行き詰った時には，本物のあるところに行って 設備を見て, 担当している研究者にあって, いろいろ話をす ることが重要だと思います。相手が本物かどうか見極める ためには，自分に相手を見抜く力がないとだめなのは，言 うまでもありません。

\section{4. おわりに}

昭和 63 年に西群馬幹線の建設に着手して以来, 11 年の 時を経て, 平成 11 年に南いわき幹線の建設は終了した。そ して，15 年経過した日本の UHV 送電線の技術が今，中国 において花開こうとしている。西の大型水力発電所の電力 を直流で市街地周辺まで輸送し，変電所間の連係に 100 万 ボルト交流送電線を使おうというものである。1 回線送電 線プロジェクトは既に架線中であり，本年 12 月には運転 開始の予定である。ここで使われている技術は基本的に日
本の技術を基盤にしたものであり，今後 2 回線送電線プロ ジェクトにも採用され, 総亘長 $1000 \mathrm{~km}$ にものぼる大UHV 送電線網が敷かれ，中国の発展に寄与するものと期待され ている。

一方，日本の UHV 送電線は，2010 年代後半の昇圧を予 定しているが，コンピュータ技術の進展に伴う検討技術の 高度化など, UHV 送電線の運用維持にむけた基盤技術の整 備が求められている。また, 先に昇圧する中国とは運用・ 保守研究の面で今後さらに密な意見交換や技術交流を行っ ていきたいと考えている。

(平成 20 年 8 月 18 日受付)

\section{文 献}

（1）関根泰次·野村喜章, 他: 特集 UHV 送電の技術開発と建設計画, オー 厶社, Vol.75, No.952 (1988)

(2) M. Kawai: "Research at Project UHV on The Performance of Contaminated Insulators Part II—Application to Practical Design", IEEE PES Summer Meetting, San Francisco, Calif. (1972-7)

(3) M. Yasui and M. Murooka: "Practical Design of AC $1000 \mathrm{kV}$ Insulator Assemblies", IEEE Trans. Power Delivery PES, Vol.3, No.1 (1988-1)

（4）安井 充:「UHV 送電線の絶縁設計」, 電学論 B, Vol.107, No.5, pp.244250 (1987-5)

（5）安井 充：「UHV 送電線の対コロナ雑音設計」, 電学論 B, Vol.107, No.4, pp.197-203 (1987-4)

(6) K. Tanabe, T. Takebe, and M. Isozaki: "Reduction of Audible Noise Using Asymmetrical Bundles for $1000 \mathrm{kV}$ Transmission Lines: Full-Scale Test Results of Akagi Test Line", IEEE Trans. Power Delivery, Vol.11, No.3 (1996-7)

(7) http://www.1000kvhhdk.com/

磯 崎 正 則 (上級会員) 1959 年 3 月 20 日生。 1983 年 3 月

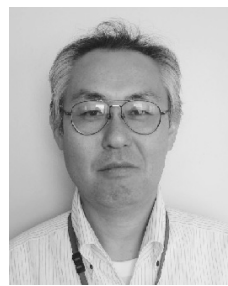
東京工業大学電気電子工学専攻修士課程修了。同 年 4 月東京電力（株）入社。現在技術開発研究所 送変電技術グループ所属。架空送電線の建設・保 守・研究開発に従事。UHV 送電線に対しては, 資 機材の開発，環境設計など, 4 線路すべてに関わっ ている。 